\title{
The Meaning and Declaration of Commercial and Civil Insolvency under the Provisions of the Jordanian Insolvency Law No. 21 of 2018
}

\author{
Murad Mahmoud AL-Shnikat ${ }^{1}$ \\ ${ }^{1}$ The Department of Public and Private Law, Faculty of Law, Al-Balqa' Applied University (BAU), Salt, Jordan \\ Correspondence: Murad Mahmoud AL-Shnikat, The Department of Public and Private Law, Faculty of Law, \\ Al-Balqa' Applied University (BAU), Salt, Jordan. Tel: 962-7-9588-8692. E-mail: Moradshnikat@bau.edu.jo
}

Received: January 7, 2020

Accepted: February 23, $2020 \quad$ Online Published: February 29, 2020

doi:10.5539/jpl.v13n1p161

URL: https://doi.org/10.5539/jpl.v13n1p161

\begin{abstract}
The present study aimed to shed a light on commercial and civil insolvency under the provisions of the Jordanian insolvency law No. 21 of 2018. It aimed to explore the meaning and procedures of insolvency under the latter law. Under the latter law, the commercial insolvency is governed by the provisions of the insolvent debtor. Under the latter law, there are two types only of insolvency; imminent and actual insolvency. Under the latter law, the ones entitled to lodge an insolvency petition are: the creditor, debtor and the officer acting on behalf of the companies control department. Contrary to that, under the repealed provisions of the Jordanian commercial law, the ones entitled to lodge a bankruptcy petition are: the creditor, debtor, the court, and the public prosecution department. Several recommendations are suggested. For instance, the researcher recommends adjusting the criteria adopted by the Jordanian legislator for identifying the ones considered insolvent debtors to include more categories. Such criteria must include greater categories, such as: banks and insurance companies. He also recommends adjusting the latter criteria in order to exclude the ones who do not meet such criteria. He recommends authorizing the court to declare the insolvent debtor by itself as officially insolvent. He believes that such a power mustn't be limited to debtors, creditors and the officer acting on behalf of the companies control department only. He recommends granting the power of lodging an insolvency petition to the court and the public prosecution department
\end{abstract}

Keywords: insolvency, insolvency declaration, imminent insolvency, actual insolvency, insolvency petition

\section{Introduction:}

Before issuing the Jordanian insolvency law No. 21 of 2018, there were several codes set by the Jordanian legislator to take measures against the funds of the debtor who fails to pay his/her debts. Having variety in such codes is attributed to the variety of the circumstances leading the debtor to experience insolvency. For instance, the debtor may be a merchant or non-merchant. Such codes may include: the commercial bankruptcy code and the civil insolvency code. Under the Jordanian civil law, the latter code is named (seizure). The civil insolvency code applies to non-merchants. The commercial bankruptcy code applies to merchants. Under such codes, the debtors shall not be requested to pay off the debts (Note 1). Article (375) of the Jordanian civil law No. 43 of 1976 sheds a light on insolvency and seizure. To be specific, it suggests (It's permitted to seize the debtor's assets in case the value of his liabilities is greater than the value of his assets). The seizure-related provisions are derived from the rules of jurisprudence.

Articles (290-477) of chapter 4 of the Jordanian commercial law No. 12 of 1966 include provisions related to bankruptcy and settlement to avoid bankruptcy. In 2018, the Jordanian legislator enacted the Jordanian insolvency law No. 21 of 2018 (Note 2). Under article 140 of the latter law, the provisions of the aforementioned articles listed in the commercial law are repealed. Under article 140, the provisions of any other law that contradict the provisions of the new insolvency law are repealed.

\section{Statement of the Problem}

The present study aims at identifying the meaning and proceedings of insolvency under the Jordanian insolvency law No. 21 of 2018

\section{The Study's Questions}

The present study aims to answer the following questions: 
1) What's the meaning of insolvency?

2) What are the types of insolvency?

3) What's meant by insolvency petition?

4) What are the proceedings of the insolvency petition?

\section{The Study's Significance}

The present study is significant. That's because it sheds a light on the Jordanian insolvency law No. 21 of 2018. This study aims to identify the provisions in this law that applies to the insolvent debtor. The latter provisions repealed several provisions that are listed in the commercial law No. 12 of 1966.

\section{Operational Definitions}

1) Insolvency: This term refers to the discontinuation or failure of the debtor to pay off his due debts in a regular manner. It may also refer to the state of having a liability value that's greater than the value of the possessed assets (Note 3).

2) Debtor: This term refers to a natural or legal person who has met the criteria of imminent or actual insolvency (Note 4).

\section{Methodology and Approach}

In order to address the study's problem, the researcher adopted a descriptive analytical approach. Through adopting the latter approach, the researcher examined the legal provisions and jurisprudential theories that are related to the meaning and proceedings of insolvency. He analyzed the relevant legislative texts and views. He also reviewed and analyzed the relevant publications, and studies. He also examined and analyzed the relevant legislative texts that are listed in national laws. That was done with taking into consideration the fact that the Jordanian insolvency law No. 21 of 2018 was enacted recently.

\section{Review of Literature}

\section{The first part: The meaning of insolvency as a legal term:}

Insolvency is a legal system through which a seizure shall be enforced on the assets of the debtor whose debts' value exceeds the value of his assets. The seizure shall be enforced in pursuant to a judgment issued by the court has jurisdiction. This judgment is issued upon the petition filed by the creditor or the debtor (Note 5)

In order to explore insolvency, the researcher shall define the meaning of this concept. He shall illustrate the difference between this term and similar terms. That is done through the two sections below:

First section: The meaning and stages of insolvency:

To explore insolvency, the researcher identifies its meaning, stages, and types, and the regulations that governs it in the recent laws. This information is illustrated through the sub-sections listed below:

First sub-section: The definition of insolvency:

The meaning of insolvency is presented below:

First: The dictionary meaning of insolvency

The opposite of insolvency is solvency. Solvency refers to possessing an assets which value exceeds the value of liabilities (Note 6). There are terms that are linked to insolvency, such as: bankruptcy, and debtor (Note 7).

Second: The technical meaning of insolvency

In jurisprudence, insolvency refers to the one who doesn't have money. Imam Malek said that the bankrupted person is the one whose liabilities' value exceeds his/her assets' value. He said that bankruptcy refers to the transition from a state of solvency into a state of insolvency (Note 8). Ibn Rushd said that bankruptcy occurs in two cases: The first case: using all the possessed assets to pay off part of the debt. The second case occurs when the person doesn't have any asset that can be used to pay off a debt (Note 9).

Through the aforementioned definitions, it can be noticed that the term insolvency is linked to the term (bankruptcy). When Abu Al-Hassan Ali Al-Tasawoli and Ahmad Ibn Rush defined the expression (bankrupted person), they used the term (insolvent). According to the latter scholars who are specialized in jurisprudence, the term (insolvency) involves poverty and occurs in two cases. The first case: using all the possessed assets to pay off part of the debt. The second case occurs when the person doesn't have any asset that can be used to pay off a debt. 
Based on the dictionary and technical meanings of (insolvency), the opposite of the term insolvency is solvency. The dictionary and technical meanings of (insolvency) are consistent with the meaning displayed in the books of the interpretation of Quran. Such books define this term based on the following verse: "And fear the Day when ye shall be brought back to Allah. Then shall every soul be paid what it earned, and none shall be dealt with unjustly" (Note 10).

Al-Fakhr Al-Razi suggests that insolvency refers to the state of not having money nor assets that can be used to pay off a debt (Note 11).

Third: The meaning of insolvency in jurisprudence:

Insolvency refers to the situation in which the value of the debtor's debts -including the current and deferred debts- exceeds the value of his assets at a specific time. In this case, the debtor is called (insolvent) (Note 12). Insolvency is defined as a legal state through which a seizure shall be enforced on the assets of the debtor whose debts' value exceeds the value of his assets. Such a seizure shall be enforced in pursuant to a judgment issued by the court has the relevant jurisdiction. This judgment is issued upon the petition filed by the creditor or the debtor (Note 13).

Insolvency may be also defined as an actual situation in which there's a gap between the liabilities' value and assets' value resulting in becoming incapable to pay off the liabilities. In this case, the debtor shall experience a state of financial distress. Thus, the debtor shall become insolvent, in case his/her liabilities are greater than his/her assets (Note 14).

Based on the aforementioned definitions, when the due debts are greater than the possessed assets, the debtor shall become insolvent. In this case, it is very likely for the debtor to smuggle his assets. That shall negatively affect the interests of the creditors.

Fourth: Insolvency under the law:

Under article 2 of the insolvency law No. 21 of 2018, insolvency refers to (the discontinuation or failure of the debtor to pay off his due debts in a regular manner. It may also refer to the state of having a liability value that's greater than the value of the possessed assets). Under article 249 of the Egyptian civil law, it's permitted for the debtor to declare that he's officially insolvent in case the possessed assets aren't adequate for paying off the debts. Under article 270 of the Iraqi civil law, (the debt of the insolvent debtor shall be considered greater than his assets, in case the creditor believe that that the debtor's assets may be lost, hidden, or transferred to another person. However, such a belief must be based on reasonable reasons and the creditor must have filed a request for the seizure of the debtor's assets. The debtor must also acknowledge that he owes the creditor money. In this case, a seizure shall be enforced on the debtor by the court).

Second sub-section: The stages of insolvency:

Under article 5 of the insolvency law, the proceedings of insolvency are categorized into three stages: 1)-the preliminary stage; 2)-the re-organization stage and 3)- the liquidation stage. The latter article suggests: (with taking into consideration the provisions listed in chapter 7 of this law, the proceedings of insolvency are categorized into the following stages:

a- The preliminary stage: This stage starts on the date on which the court decides to declare the debtor as officially insolvent. During this stage, the names of the creditors and the value of the debt shall be identified. Data shall be collected about the business of the creditor. Such data shall be analyzed to identify the reasons that led to insolvency. They shall be analyzed to identify whether the debtor's enterprise can survive in the market.

b- The re-organization stage: It is preceded by the preliminary stage. During the second stage, an agreement is concluded between the debtor and his/her creditors about the re-organization plan. That shall occur, unless a liquidation request is applied before this stage starts.

c- The liquidation stage: It's designated for liquidizing the assets of the debtor. It starts when it's difficult to carry out the re-organization process. That may occur because the business operations of the debtor shall be terminated. It may occur because it's difficult to get an approval on the re-organization plan. It may occur because it's difficult to execute the re-organization plan.

The preliminary stage starts on the date on which the insolvency is officially declared. During this stage, a list including the names of all the creditors of the debtor shall be drafted. Information shall be collected about the concerned company or enterprise. During this stage, the reasons leading to experiencing insolvency by the company or the enterprise shall be analyzed. During this stage, an assessment shall be conducted to identify whether the concerned enterprise can continue or not. In case the concerned enterprise can't continue, the 
liquidation stage must start. However, in case the concerned enterprise can't continue, the re-organization stage must start (Note 15).

During the second stage, an agreement is concluded between the debtor and his/her creditors about the re-organization plan. During this stage, all the executive measures taken by the company and the interests and fines incurred by the company shall be put on hold (Note 16).

If it was found that the concerned company or enterprise can't survive in the market, the liquidation stage shall start. During the liquidation stage, the insolvency agent (or liquidator) shall be assigned. The latter person shall carry out all the required measures and operations for closing the company or the enterprise. He shall ensure that the debtor is paid off all the debts that people owe him. He shall turn the available assets into cash. He shall pay off the debts and financial claims. In case an amount of money remained after doing that, it shall be distributed to the owners of the company or the enterprise (Note 17).

The third sub-section: Types of insolvency:

There are two types of insolvency; legal and actual insolvency. The legal insolvency is a (legal state that occurs when the value of the due debts of the debtor exceeds the assets he possesses. In this state, the debtor must officially disclose his insolvency under a court judgment) (Al-Shahawi, 2010, p. 121) (Note 18). The actual insolvency refers to a (current state that occurs when the value of the current debts exceeds the assets that the debtor possesses. That applies whether the debts are due or non-due) (Note 19) (Al-Sanhuri, 1982, p.1565).

In this regard, one asks: (What's the stand of the Jordanian legislator on both types of insolvency?).

Article 375 of the Jordanian civil law addresses implicitly the legal insolvency. To be specific, it states: (it's permitted to seize the assets of the debtor in case his current debts exceed the assets he possesses). Thus, the Jordanian legislator acted legislative texts that regulate insolvency. He also imposed major restrictions on the debtor. He believes that it was necessary to enact provisions regulating civil insolvency. Meeting the criteria of civil insolvency shall lead to experiencing major implications by the insolvent debtor.

In order to meet the insolvency criteria listed in articles (375-386) of the Jordanian civil law, the assets of the debtor mustn't be enough to pay off his current debts only. Thus, to meet this criteria, one must be experiencing actual insolvency only (Note 20) (Al-Far, 2008: 112).

Some jurists (Note 21) (Al-Sanhuri, 1982: 1575) suggest that actual insolvency is more general than legal insolvency. Thus, the one experiencing actual insolvency may not be necessarily experiencing legal insolvency. However, the one experiencing legal insolvency is experiencing actual insolvency for sure.

Under the Jordanian insolvency law No. 21 of 2018, there are types of insolvency; imminent and actual insolvency. The latter law defines imminent insolvency through article 2 as being: (the state in which it's expected that the debtor shall lose in the future his capability to pay off his debts when they become due within 6 months. That applies though the debtor is currently is capable to pay off these debts). As for the actual insolvency, it refers to the legal insolvency or insolvency in general. To be specific, it refers to (the discontinuation or failure of the debtor to pay off his due debts in a regular manner. It may also refer to the state of having a liability value that's greater than the value of the possessed assets).

Thus, the legal insolvency may end before the actual insolvency ends. It ends under a court judgment, provided that the insolvent debtor has paid off his current debts. It can also end by the force of the law, provided that a specific period has passed after the official disclosure of insolvency. The legal insolvency may end with having debts that exceed the assets possessed. In this case, one would be still be experiencing insolvency. In other words, one may experience actual, legal, and actual insolvency respectively.

Second Section: Differentiating between insolvency and other similar terms:

To differentiate between insolvency and other similar terms, a comparison must be conducted between insolvency and these terms. This comparison is presented below:

First sub-section: Differentiating between insolvency and incapability to pay off a debt:

Based on the Jordanian civil law, the judgment issued in case one failed to pay off a debt shall be made based on the reasons of such failure. Article 246 of the latter law states: (1-In the contracts that are binding, in case one of the parties doesn't pay off his/her financial contractual obligations, the other party is entitled to claim for executing or terminating the contract after notifying the debtor 2-The court is entitled to oblige the debtor to execute the contract immediately or give him/her a specific duration to do so. It's entitled to terminate the contract and oblige the debtor to pay a compensation in case it's required). Article 334 of the Jordanian civil law states: (1-The financial obligation must be paid off, once it's considered officially the obligation of the debtor. 
That applies even if there isn't any agreement or written prove that suggests that. 2- In some exceptional cases, it's permitted for the court to give the debtor a specific duration to pay off his financial obligation if necessary. That applies, provided that no major damage shall be caused to the creditor).

In this regard, one may ask: (what's meant by incapability to pay off a debt?), (When would the debtor considered incapable to pay off a debt?), (Is the incapability to pay off a debt similar to insolvency?).

To answer these questions, a comparison must be conducted between incapability to pay off a debt and insolvency in theoretical and practical aspects as shown below:

First: incapability to pay off a debt and insolvency in theoretical aspects.

Incapability to pay off a debt means that the debtor is incapable to pay off the debt. Fulfillment of an obligation shall lead to the termination of this obligation. The one who owes someone money must fulfill his/her obligation in cash at the agreed upon time or make a settlement. There shall be no alternative nor any other way for fulfilling this obligation (Note 22).

As for insolvency, it refers to having liabilities that are greater than assets (actual insolvency). Thus, incapability to pay off a debt means that the debtor is incapable to pay off his financial obligations -including due debts- due to the adequacy of the possessed funds. Under article 246 of the Jordanian civil law, the court may issue a judgment obliging the debtor to pay a compensation due to the delay of the debtor in paying off a financial obligation. Under this article, that applies provided that the debtor is capable to pay off the debt. In this case, the creditor must prove that the debtor is capable to pay off the debt. The court must take into consideration the nature of the assets possessed by the debtor and the time needed to have the required amount of money available. Under article 343 of the Jordanian civil law, the debtor can't get an additional period of time by the court to pay off his debt. That applies, unless the judge finds that the debtor is capable to pay off the concerned debt. Such capability is decided based on the debtor's financial status, liabilities and duties. Thus, the debtor must be worth getting the additional period of time based on his financial profile. The additional period mustn't be given to the debtor who didn't fulfill his obligation intentionally or showed a major failure is fulfilling it. It mustn't be given to the insolvent debtor who shall not become capable of paying off the obligation (Note 23).

The debtor's incapability to pay off an obligation makes one presumes that actual insolvency is experienced by the debtor. Everyone who is not capable of paying off his due debts is deemed incapable of paying off his deferred debts, but the opposite may not be always true. The insolvent debtor may be experiencing actual insolvency and capable of paying off the debt. There is no connection between having inadequate money to pay off the (due or undue) debts and capability to pay off the debts (Note 24).

Incapability to pay off a debt means that the debtor's funds are inadequate to pay off the due debts only. It's narrower expression than actual insolvency. Actual insolvency refers to the discontinuation or failure of the debtor to pay off his due debts in a regular manner. It may also refer to the state of having a liability value that's greater than the value of the possessed assets.

Second: Incapability to pay off a debt and insolvency in practical aspects:

Such incapability refers to the debtor's incapability to pay off due debts due to having inadequate funds. As for insolvency, it refers to having debts that are greater than assets. From a practical perspective, the researcher believes that both of those expression could be considered synonyms. Insolvency often occurs due to having inadequate assets to pay off the due debts (i.e. incapability of the debtor to pay off the due debt).

It's difficult to consider the debtor insolvent just because there is an imbalance between assets and liabilities. The increase of liabilities and the decrease of assets are just indicators for experiencing insolvency. As for the incapability of the debtor to pay off the debts, it confirms that the debtor is experiencing insolvency. Insolvency is always connected to the debtor's incapability to pay off his due debts. Hence, the Jordanian court is permitted to seize the insolvent debtor's assets in order for creditors to get their funds back (Note 25).

The seizure lawsuit involves a request for refraining the debtor from disposing assets, in order to pay off the debts. Through filing such a lawsuit, measures can be taken, such as: seizing and selling real estates (Note 26). The Jordanian legislator entitled people to file such a lawsuit in order to protect the creditors from the fraudulent acts made by the debtor. Such acts shall negatively affect the interests of the creditors (Note 27).

The second sub-section: Differentiating between insolvency and discontinuation to pay off a debt

Under the Jordanian insolvency law No. 21 of 2018, the legislator repealed the bankruptcy and settlement-related provisions listed in articles 290-477 in the Jordanian commercial law No. 12 of 1966. It's necessary to shed a light on some of the repealed legislative texts to differentiate between insolvency and discontinuation to pay off 
a debt.

The Jordanian commercial law sheds a light on the meaning of (discontinuation to pay off a debt) through the commercial insolvency code. Any merchant who experiences financial distress may disclose officially his bankruptcy. Article 316 of the Jordanian commercial law states: (Along with keeping the provisions of the previous chapter enforced, bankruptcy refers to the merchant's discontinuation of paying off commercial debts. It refers to any merchant who supports his financial confidence only through using illegitimate means).

Bankruptcy is not considered official unless there is a court judgment. Discontinuation to pay off a debt before issuing such a judgment shall not lead to any consequences. That applies unless the law states otherwise (cited from article $317 / 1$ of the Jordanian commercial law). Merchant creditor is entitled to file a disclosure petition against the merchant debtor who must pay him off a due commercial debt. That applies in case the merchant debtor experienced a financial distress that led to the discontinuation of paying off the debt. Such discontinuation shall indicate that the merchant debtor experienced financial distress, unless otherwise was proved (Note 28). The discontinuation of paying off a debt means that the merchant is incapable to pay off the current debts. Such discontinuation is required to issue a court judgment that discloses the debtor as officially bankrupted. Such a judgment shall lead to legal implications affecting the debtor and the creditor (Note 29).

In application to that, the court of cassation issued the following judgment: (1- The discontinuation of paying off a debt means that the debtor refrained from paying off the debt installments on the due dates. Thus, it's permitted to consider the merchant who discontinues paying off the debt officially bankrupted. That applies even if the debtor is solvent and even if his assets' value exceed his debts' value. For instance, a merchant debtor may be having real estates which liquidation shall enable the debtor to pay off the debts. However, the merchant debtor may be incapable to dispose these real estates, because selling them requires much time. Such incapability may be attributed to any other reason. In such a case, the circumstances shall prevent the merchant debtor from paying off debts. 2-It's not enough for the merchant debtor to discontinue paying off a debt to consider it an official discontinuation. In fact, such discontinuation must indicate that the merchant debtor is experiencing financial distress and his enterprise shall not survive in the market anymore. It must be proven that it's not possible for his financial position to improve. However, if the discontinuation of the merchant is attributed to technical problems or problems that can be handled very fast, it shall not be deemed as a discontinuation under the law. Thus, a court judgment declaring the merchant as officially bankrupted can't be issued in this case) (Note 30).

Insolvency is a general state that applies to merchant and non-merchant debtor. Discontinuation of paying off a debt is a special state that is experienced by the bankrupted merchant. What are the similarities and differences between those two? Does insolvency lead to the discontinuation of paying off a debt? Does such discontinuation means that the debtor is insolvent?

To answer this question, a comparison must be conducted between insolvency and the discontinuation of paying off a debt in theoretical and practical aspects.

First: Insolvency and discontinuation of paying off a debt in theoretical aspects

Under article 2 of the Jordanian insolvency law No. 21 of 2018, insolvency refers to (the discontinuation or failure of the debtor to pay off his due debts in a regular manner. It may also refer to the state of having a liability value that's greater than the value of the possessed assets). Thus, insolvency is determined based on one's liabilities and assets. The greater the value of the assets, the greater the solvency level shall be. The greater the value of the liabilities, the greater the insolvency level shall be. Under the Jordanian commercial law, the merchant can't be considered bankrupted, unless he experienced financial distress that led to the discontinuation of paying off due commercial debts. That applies whether he's solvent or insolvent. Under the Jordanian commercial law, insolvency is determined based on the failure to pay off the debts on their due dates.

The merchant may fail to pay off his due debt which requires disclosing his bankruptcy. That occurs though he's solvent (i.e. the asset value is greater than liabilities). That may occur when the assets are real estates that can't be sold fast to pay off the debts. It may occur when there are debts that must be paid off to the merchant, but they aren't due yet. The merchant who pay off his debts -through borrowing money- though he's bankrupted can't disclose his bankruptcy officially. In some cases, the court may consider the debtor as has been discontinuing paying off the debt and issue a judgment declaring the debtor as officially bankrupted. That may occur in case the debtor used illegitimate means to pay off the debts in order to hide information about his financial position (Note 31). This approach is adopted by the Jordanian legislator through article 316 of the Jordanian commercial law. This article includes the following statement: (It refers to any merchant who supports his financial confidence only through using illegitimate means). 
The legislator doesn't require proving insolvency. He just requires proving the discontinuation of paying off debts. That's attributed to the easiness of proving such discontinuation and the difficulties faced when proving insolvency. It's attributed to the long period of time required for carrying out the proceedings of identifying the values of the debtor's assets and liabilities (Note 32).

The discontinuation that permits declaring someone bankrupted officially requires experiencing financial distress by the merchant debtor. That applies whether the merchant debtor is insolvent or solvent. Such discontinuation means that the debtor failed to pay off the debts on their due dates. As for insolvency, it refers to the discontinuation or failure of the debtor to pay off his due debts in a regular manner. It may also refer to the state of having a liability value that's greater than the value of the possessed assets

Second: Insolvency and discontinuation of paying off a debt in practical aspects:

When conducting a comparison between insolvency and discontinuation of paying off a debt in practical aspects, exaggeration shouldn't be made. Merchants usually do not stop paying off debts in order to avoid filing bankruptcy petition against him. A merchant usually stop paying off debts in case he used all his funds to pay off debts. After finishing the liquidation process, it is rare to find out that the debtor has more assets than liabilities. The merchant doesn't disclose his financial position, unless his debts exceed his assets and his enterprise can't survive in the marketplace (Note 33).

The difference between insolvency and discontinuation is clear in theoretical aspects. The similarity between them is also clear in practical aspects. Insolvency must lead to the discontinuation of the debtor to pay off his due debts. It's not likely to see the creditor making false claims against the debtor, if the debtor is paying off the debt installment. That's because the creditor shall not gain any benefit from filing a lawsuit requesting to seize the debtor's assets in this case (Note 34). The merchant's discontinuation of paying off debts doesn't occur, unless he is insolvent. Jurisprudence and commercial judiciary suggest that discontinuation isn't considered discontinuation by just having the debtor discontinuing paying off the debt installments. In fact, they suggest that such discontinuation must indicate that there's an ongoing financial deficit that shall negatively affect the creditors' interests (Note 35).

Thus, in case the merchant discontinued paying off debts due to a financial distress that shall be resolved fast, such discontinuation doesn't allow the court to disclose the debtor's bankruptcy officially. In order to disclose the debtor's bankruptcy officially, discontinuation must be attributed to financial deficit. As for insolvency, it must lead to the discontinuation of paying off due debts.

Second part: Insolvency petition and proceedings

The researcher aimed to identify the position of the one filing an insolvency petition and the court that has jurisdiction over this matter. He aimed to identify the conditions that must be met for issuing a court decision declaring a person as officially insolvent. He aimed to identify the content of such a court decision. These things are identified below

First part: The position of the one filing an insolvency petition and the court that has jurisdiction

These things are identified below

First sub-part: The position of the one filing an insolvency petition

In case imminent and actual insolvency were experienced, the one entitled to file insolvency petition is the debtor. In case actual insolvency was experienced, the one entitled to file insolvency petition is the creditor. In case actual insolvency was experienced and the debtor is a company, the officer acting on behalf of the companies control department shall be the one entitled to file insolvency petition. However, priority is given to the insolvency petition filed by the debtor (cited from article 6 of the Jordanian insolvency law). The latter law defines imminent insolvency through article 2 as being: (the state in which it's expected that the debtor shall lose in the future his capability to pay off his debts when they become due within 6 months. That applies though the debtor is currently is capable to pay off these debts).

One may ask: (When should one file the insolvency petition?)

The insolvency petition must be filed within two months since the actual or presumed date on which one acknowledged that he's experiencing actual insolvency. Article 7 of the Jordanian insolvency law states the following:

(A-The debtor -or any of the ones running his enterprise if it's legal person- can file an insolvency petition within two months since the actual or presumed date on which one acknowledged that he's experiencing insolvency. 
B-The above paragraph doesn't apply to imminent insolvency

C-The ones mentioned in paragraph (A) shall be held responsible for the damage caused for violating this article. In case such a violation was committed, the court is permitted to issue a judgment that prevents the violator from conducting any business transaction for a period that isn't less than 1 year and doesn't exceed 5 years).

Second sub-section: The court that has jurisdiction in this regard:

The insolvency petition must be filed to the court that has jurisdiction in order to look in it. Article 2 of the of the Jordanian insolvency law No. 21 of 2018 includes the following statement: (The court: It's the court of first instance that has jurisdiction to look into the interests of the debtor).

Thus, under the Jordanian law, the court of first instance is the court that has jurisdiction to look into the insolvency petition.

Under the repealed bankruptcy-related provisions of the Jordanian commercial law, the Jordanian court of cassation issued a judgment stating the following: (The judgement that declares someone as officially bankrupted must be issued by the court of first instance which is located near the Business Institution. The latter court has jurisdiction to look into all the lawsuits related to bankruptcy rules. The appeal-related provisions in articles 316, 317 and 323 of the commercial law apply to such lawsuits) (Note 36).

The second section: Conditions for issuing a court judgment that declares someone as officially insolvent and the content of such a judgment:

Under the Jordanian insolvency law No. 21 of 2018, when the debtor files an insolvency petition, he must acknowledge that he has been experiencing imminent or actual insolvency (Note 37).

What are the documents that must be attached with the insolvency petition?

The documents that must be attached with the insolvency petition include the following ones:

1) A report that includes the reasons behind experiencing insolvency and an analysis for the future financial status of the enterprise

2) A certificate showing the date on which the debtor registered the enterprise and the changes that occurred to the enterprise in sequence.

3) The accounting and financial records of the debtor. Such records must include: the budget, financial data, and commercial records for the three fiscal years that precede the date on which the petition was filed.

4) A statement that includes information about the movable and immovable assets of the debtor. The value and information of such assets must be identified through such a statement. This statement must identify whether there are measures taken against the debtor's assets or not. It must identify whether the debtor's assets serve as a security or not.

5) A list including all the names of the creditors and their addresses and the amount of money that must be paid off to each creditor. This list must include data about the debs and their due dates.

6) A statement that includes data about the legal procedures taken by the debtor or against him

7) Any other data related to the petition (Note 38).

After filing the petition by the debtor, the court of first instance shall look into the petition. If the petition meets the conditions listed in articles 6-8 of the Jordanian insolvency law and the court found that the debtor is insolvent, the court shall issue a judgment that requires declaring the debtor as officially insolvent within 30 days since the date on which the petition was filed on. No other measure is needed (Note 39).

If the court of first instance found that the data in the petition violates article 8 of this law, the court shall give the debtor a period of 15 days to address this violation. Otherwise, the petition shall be rejected before processing it, because the requirements are not met (Note 40).

Articles 10 and 11 of the Jordanian insolvency law shed a light on the cases in which it's permitted to file a petition by the creditors of the insolvent debtor and the officer acting on behalf of the companies control department. Article 10 states the following: (A-Any creditor filing an insolvency petition must attach a proof indicating that a due debt must be paid off to him. Paying off this debt must be unconditioned.

B-If the petition is filed by the creditor or the officer acting on behalf of the companies control department, the one filing the petition must prove that the debtor is experiencing actual insolvency.

$\mathrm{C}$-The things listed below serve as indicators of experiencing actual insolvency: 
1) An indicator shall be considered existent, in case the creditor filing the petition or any other creditor initiated the execution measures that must be taken against the debtor in pursuant to the law of the proceedings and couldn't get back his funds.

2) If executive seizure is enforced on all of the debtor's assets, an indicator shall be considered existent

3) If the debtor sold his assets or used a mean to avoid having them seized, an indicator shall be considered existent

4) If the debtor is a natural person and his place of residence become suddenly unknown, an indicator shall be considered existent

5) If the debtor is a legal person and shut down the business, an indicator shall be considered existent

6) A court issued a judgment acknowledging the validity of the insolvency proceedings that were taken by a foreign country.

D- The debtor is entitled to claim that he's not experiencing any of the states mentioned in paragraph C of this article. He is entitled to prove his capability to pay off debts. He is entitled to claim that he doesn't owe the creditor any money).

Article 11 of the insolvency law states: (A-If the court finds that the insolvency petition -filed by the creditor or the officer acting on behalf of the companies control department- meets the conditions listed in article 10 , the court shall be responsible for notifying the debtor about the petition and its attached documents. Such notification must be sent within 5 days since the data on which the petition was filed on.

B-The debtor is entitled to object to such petition within 10 days since the date on which he was notified on. He must provide the relevant evidence supporting his objection. If the debtor didn't object and found that the conditions listed in the law are met, the court shall issue a judgment that requires disclosing insolvency within 15 days since the date on which period mentioned in this article ends).

If the debtor filed an objection to the petition filed by the creditor or the officer acting on behalf of the companies control department, the court must hold a hearing or reviewing session within 5 days since the date of filing the petition. After sending the notification, the court shall hold a hearing session and request the concerned parties to attend it. That must be done within 15 days since the date on which the petition was filed on. During this session, the court must listen to the parties' statements and issue its judgment fast within 10 days since the date of holding the last session or within 15 days since the date on which the petition was filed on by the debtor (Note 41).

The content of the judgment that declares someone as officially insolvent:

Under paragraphs (a, b, c, d, e and f) of article 13 of the Jordanian insolvency law No. 21 of 2018, the content of such a judgment is identified below:

1) Personal and commercial data -including the address- of the concerned parties

2) If the petition was filed by the creditor or the officer acting on behalf of the companies control department, the judgment must oblige the debtor to submit the required documents identified through article 8 of the insolvency law within 10 days since the date on which the insolvency declaration judgment was issued on.

3) Such a judgment must include the powers of the debtor in managing his assets. It must include any restrictions imposed on the debtor in managing his assets. It must enforce the ones who borrowed money from the debtor to pay off their debts to the insolvency agent.

4) Such a judgment must assign the insolvency agent along with identifying his name, national identification number, number of professional certificate, address phone number, and powers in managing the insolvent's assets

5) Such a judgment may include the protective measures that are taken by the court to protect the insolvent's assets during the period that precedes assigning an insolvency agent.

6) Such a judgment must request the creditors of the debtor to submit their claims to the insolvency agent. That must be done within 30 days since the date of publishing the insolvency declaration judgment in the official newspaper.

As for the duties of the insolvency agent, article 14 of insolvency law states: (A-Within 5 days since the date on which the insolvency declaration was issued on, the insolvency agent must notify the creditors whose names are listed in the debtor's record. This agent must ask those creditors to submit their claims in accordance with the 
procedures listed in the law. B-This agent must notify the income and sales tax department, social security corporate, the association that the debtor is registered in and the employee association, if exists).

Thus, this agent's duties are:

1) Notifying the creditors whose names are listed in the debtor's record. This agent must ask those creditors to submit their claims in accordance with the procedures listed in the Jordanian insolvency law.

2) Notifying the income and sales tax department, social security corporate, the association that the debtor is registered in and the employee association, if exists).

Is the judgment issued by the court of first instance deemed final or an appeal can be filed against it?

Paragraph a /article 15 of the insolvency law states: (An appeal may be filed against the insolvency declaration judgment issued by the court. That applies within 10 days since the date of publishing judgment in the newspaper or notifying the one concerned about it). Under paragraph b/article 15 of the insolvency law, such an appeal doesn't stop the implementation of the insolvency proceedings. The court of appeal is entitled to take protective measures that it deems necessary.

The permissibility to file an appeal to the court of cassation against the judgment issued by the court of appeal in this regard depends on the concerned fund value. To be specific, if the concerned fund value exceeds 10,000 JDs, an appeal to the court of cassation can be field directly. If the concerned fund value is less than that or unknown, filing such an appeal requires getting an approval by the head of the court of cassation or the one acting on his behalf (Note 42).

Under the repealed provisions of the Jordanian commercial law, the Jordanian court of cassation issued the following judgment: (1-The bankruptcy petition isn't considered a case which financial value is identified. That's because it doesn't involve a claim for a specific financial value. Article 191/1/2 of the civil proceeding law No. 14 of 2001 suggests that it's permitted to file an appeal before the court of cassation against the judgment issued by the court of appeal, provided that the concerned fund value exceeds 5,000 JDs. Otherwise, filing such an appeal requires getting an approval by the head of the court of cassation or the one acting on his behalf. 2-Under article 10 of the court formation law, it's not permitted to file an appeal against the judgments issued by the court of appeal in the lawsuits which value exceeds 5,000 JDs without getting an approval by the head of the court of cassation or the one acting on his behalf. 3-If the one filling the petition isn't claiming for a specific amount of money, the judgment in such a lawsuit can't be appealed without getting an approval by the head of the court of cassation or the one acting on his behalf (Note 43).

The Jordanian court of cassation issued a judgment stating the following: (A bankruptcy petition may be filed in pursuant to article 316 of the commercial law. This case is a case which value isn't specified. Therefore, the appeal against the judgment issued by the court of appeal in such a case requires getting an approval by the head of the court of cassation. In case the one filling the appeal didn't get such an approval, the appeal shall be rejected before processing it, because it doesn't meet the requirements (Note 44)).

When issuing the final court judgment that declares someone as officially insolvent, this judgment must be published in the newspaper. The published judgment must include information about the debtor, and the restrictions enforced on the debtor in managing and disposing his assets. It must identify the name of the insolvency agent. It must request the creditors to submit their claims. The judgment of declaration is considered valid starting from the date of publishing it. The court must oblige the debtor or the insolvency agent to disclose the insolvency declaration judgment through publishing it in a local daily newspaper or a daily newspaper in the country that the debtor is conducting a business activity in. That shall be done in accordance with the measures specified by the court. The insolvency declaration judgment must be registered in the company record at the company control department. It must be registered in the insolvency record and in any other record that belongs to the debtor. It must be posted to the debtor's website, if found (Note 45).

\section{Conclusion: Results and Recommendations}

Under article 140 of the Jordanian insolvency law No. 21 of 2018, the legislator repealed several provisions listed in the commercial law. The latter article repealed the provisions mentioned in any other law which are inconsistent with the provisions of the new insolvency law. The Jordanian insolvency law No. 21 of 2018 repeals the provisions listed in commercial law which are enforced on commercial bankruptcy. It also repeals the seizure provisions that are listed in civil law and enforced on civil bankruptcy. It enforced unified provisions on such commercial bankruptcy and seizure.

The Jordanian legislator adopted a new approach in carrying out the insolvency proceedings. He expanded the 
criteria used for identifying the ones who may be experiencing the insolvency. He also provided the insolvent debtor with many opportunities to resolve the financial problems that might lead him to disclose his insolvency officially. Thus, he assists the insolvent debtor in overcoming his financial distress in order to enable him to survive in the marketplace. That's done to reduce the probabilities of shutting down the business due to a financial crisis.

Several results are reached and several recommendations are proposed

\subsection{Results}

1) The Jordanian legislator identified the ones who may be called (insolvent debtor) and the provisions that apply to them. He suggest that the insolvent debtor may be any one practicing a business activity, including a legal person (e.g. civil companies and the companies owned by the government). He suggest that the insolvent debtor may include merchants, the owners of institutions, professionals who are registered in professional associations and authorized to work in pursuant to the current legislations.

2) The Jordanian insolvency law identifies the ones who can't be considered insolvent debtors, such as: banks, insurance companies, associations, clubs, ministries, public departments, and public institutions. That applies unless the council of ministers decides to consider them so. Under the Jordanian insolvency law, the ones who can't be considered insolvent debtors may include: natural persons whose affairs are governed by the civil law. Under the Jordanian insolvency law, the ones who can't be considered insolvent debtors may include

3) Under the repealed provisions, if the merchant discontinued paying off the debt installments due to having limited amount of cash, a bankruptcy petition may be filed against the merchant. Under the new insolvency law, the bankruptcy petition can't be filed in such a case.

4) Without having article 140 of the insolvency law, there shall be inconsistency between this law and the provisions of the bankruptcy and settlement in articles (290-477) of the commercial law of 1966

5) The Jordanian legislator introduced a new concept; imminent insolvency (expecting to experience insolvency in the near future). He sheds a light on the capability to file an insolvency petition in such a case

6) Under Jurisprudence, there are two types of insolvency; legal and actual insolvency. Under the new Jordanian insolvency law, there are two types of insolvency; imminent and actual insolvency. Article 2 of the Jordanian insolvency law defines imminent insolvency as: ( the state in which it's expected that the debtor shall lose in the future his capability to pay off his debts when they become due within 6 months. That applies though the debtor is currently is capable to pay off these debts). As for the actual insolvency, it refers to the legal insolvency or insolvency in general. To be specific, it refers to (the discontinuation or failure of the debtor to pay off his due debts in a regular manner. It may also refer to the state of having a liability value that's greater than the value of the possessed assets).

7) Under the Jordanian insolvency law, the ones entitled to file the insolvency petition are: the debtors, creditors and the officer acting on behalf of the companies control department only. Under the repealed provisions of the commercial law, the ones entitled to file the bankruptcy petition are: the creditor, debtor, the court, and the public prosecution department.

8) The Jordanian insolvency law permits the insolvent debtor to manage his assets under the supervision of the insolvency agent. Thus, the insolvent debtor is entitled to keep following up the legal measures taken in pursuant to the lawsuits filed against him and the ones filed by him

\subsection{Recommendations}

1) The researcher recommends adjusting the criteria adopted by the Jordanian legislator for identifying the ones considered insolvent debtors. Such criteria must include more categories, such as: banks and insurance companies. This criteria must be more specific. For instance, provisions of the insolvency law must shed a light on the companies that are affiliated with the government and permit considering them as insolvent debtors

2) The Jordanian legislator should give the court the power to officially disclose the debtor as being insolvent by itself. Such right shouldn't be limited to debtors, creditors and the officer acting on behalf of the companies control department only

3) The researcher recommends granting the power of lodging an insolvency petition to the court and the public prosecution department

4) The researcher recommends holding training courses for judges, lawyers, employees in companies, and merchants about the provisions of the new insolvency law. That's because this law is a procedural law that 
includes much information about requirements, documents and periods of time. In other words, it's a big law that includes 142 articles

5) The researcher recommends providing university students with a course about insolvency. Through such a course, the Jordanian insolvency law No. 21 of 2018 must be examined and analyzed.

6) The researcher recommends issuing codes that include applications for insolvency law. Such codes are mentioned in article 141 of the latter law.

\section{Acknowledgments}

The researcher would like to thank Balqa' Applied University (BAU) for providing him with much support.

\section{References}

Al-Dafeery. (2011). Insolvency state in the Kuwaiti civil law. Rights Journal. The University of Kuwait, 35(1).

Al-E'kaili, A. (2011). Al-Waseet: Illustration for the commercial law. Part No. 3: The provisions of bankruptcy and the settlement that avoid one getting bankrupted: A comparative study (4th ed.). Al-Thaqafeh Publishing and distribution house. Amman.

Al-Far, A. A. (2008). Provisions regulating commitment: The effects of having rights under the civil law (1st ed.). Al-Thaqafah publishing and distribution Journal. Amman.

Al-Jbouri, Y. M. (2003). Al-Wajeez: Illustration for the Jordanian civil law. Part 2. The provisions regulating commitment (1st ed.). Al-Thaqafah publishing and distribution house. Amman.

Al-Nemrat, O. (2005). The legal effects of the bankrupt's transactions in the doubt period according to the Jordanian commerce law: A comparative study with Egyptian commerce law MA thesis. Arab Amman University.

Al-Qairawani, A. B. A. A. (389 AH). The message. Mustafa Albab Al-Halabi publishing and distribution house. Beirut.

Al-Sanhuri, A. A. A. (n.d.). Al-Waseet: Illustration for the civil law. Part 2. The theory of commitment from a general perspective. Second volume. The impact of commitment. Al-Feker Al-Arabi Publishing and distribution house. Cairo.

Al-Shahawi, Q. A. A. (2010). The theory of the right to prison someone and the case of civil insolvency (1st ed.). Al-Ma'aref publishing and distribution. Alexandria.

Al-Tarawneh, B., \& Melhem, B. (2017). Illustration for the commercial law: The principles of the commercial law (4th ed.). Al-Maseera publishing and distribution house. Amman.

Al-Tasawoli, A. A. A. A. A. (n.d.). Happiness in illustrating work of art (2nd ed.). Mustafa Albab Al-Halabi publishing and distribution house. Beirut.

Ammar, M., \& Al-Sheikh, B. S. (2017). The thematic and procedural aspects of civil insolvency: A comparative study between the Algerian and Egyptian laws. Dafater Journal of Law. Morocco, (2-3).

Haitham, S. M. (1999). Insolvency and bankruptcy under the legislations of the Republic of Yemen. The Journal of Yemeni Studies, (60-61).

Ibn Rushd, A. A. A. M. (n.d.). Bedayet Almujtahed and Nehayet Al-Muqtased. Al-Kuleyat Alazhareye publication and distribution house. Cairo. Part1.

Khalil, A. M. (2004). The provisions of commercial bankruptcy and civil insolvency. Al-Matbooat Al-Jameye publishing and distribution house. Alexandria.

Marqas, S. (1992). Al-Wafi: Illustration for the civil law. Part 2: Commitment. Volume 4. Provisions of commitment (2nd ed.).. Al-Feker Al-Arabi publication and distribution house. Cairo.

Saeed, F. S. (2014). The legal regulations governing civil insolvency. MA thesis. The Middle East University.

The Egyptian Civil law No. 131 of 1948.

The Jordanian civil law No. 43 of 1976.

The Jordanian commercial law No. 12 of 1966.

The Jordanian insolvency law No. 21 of 2018. 


\section{Notes}

Note 1. Al-E'kaili, Aziz, Al-Waseet: Illustration for the commercial law. Part No. 3: The provisions of bankruptcy and the settlement that avoid one getting bankrupted: A comparative study. Al-Thaqafeh Publishing and distribution house. Amman. $4^{\text {th }}$ edition.2011. p.16-17.

Note 2. A post posted on page No. 2640 of the official newspaper/ issue No. 5514/ date:16/5/2018. It was considered valid for 180 days since the day it was posted on.

Note 3. Article 2 of the Jordanian insolvency law No. 21 of 2018.

Note 4. Article 2 of the Jordanian insolvency law No. 21 of 2018.

Note 5. Al-Jbouri, Yaseen Mohammad. Al-Wajeez: Illustration for the Jordanian civil law. Part 2. The provisions regulating commitment. Al-Thaqafah publishing and distribution house. Amman. $1^{\text {st }}$ edition. 2003. P.366.

Note 6. Lisan Al-Arab Dictionary by Ibn Manthour. Al-Ma'aref publishing and distribution house. Cairo. 1999. Part 4. Chapter E. p.184-185.

Note 7. Khalil, Ahmad Mahmoud. The provisions of commercial bankruptcy and civil insolvency. Al-Matbooat Al-Jameye publishing and distribution house. Alexandria. 2004, p.18.

Note 8. Al- Tasawoli, Abu Al-Hassan Ali Abed Al-Salam. Happiness in illustrating work of art. Mustafa Albab Al-Halabi publishing and distribution house. Beirut. $2^{\text {nd }}$ edition. 1370-1951. P.246.

Note 9. Ibn Rushd, Abu Al-Walid Ahmad bin Mohammad. Bedayet Almujtahed and Nehayet Al-Muqtased. Al-Kuleyat Alazhareye publication and distribution house. Cairo. Part1. P.348.

Note 10. Al-Bakrah Surah. Verse No. 280.

Note 11. Al-Qairawani, Abdullah Bin Abed Al-Rahman. The message. Mustafa Albab Al-Halabi publishing and distribution house. Beirut. 389 AH. P.138.

Note 12. Marqas Sulaiman. Al-Wafi: Illustration for the civil law. Part 2: Commitment. Volume 4. Provisions of commitment. Al-Feker Al-Arabi publication and distribution house. Cairo. 1992. $2^{\text {nd }}$ edition. P.398.

Note 13. Al-Jbouri, Yaseen Mohammad. Al-Wajeez: Illustration for the Jordanian civil law. P.366.

Note 14. Saeed, Fahed Saeed. The legal regulations governing civil insolvency. MA thesis. The Middle East University. 2014. P.14.

Note 15. Article 66 of the Jordanian insolvency law No. 21 of 2018 states: (The preliminary stage ends in case

A- The specified period for filing an appeal against the decision of approving the list of properties, or list of creditors has ended. The preliminary stage ends in case a court judgment was issued upon the appeal filed against any of those lists.

B- The court issued a judgment for starting with the stage that follow the preliminary stage before issuing a judgment upon the appeal filed against any of those lists. That applies after carrying out the procedures listed in article 64 of this law)

Note 16. Article 67 of the Jordanian insolvency law No. 21 of 2018 states: A-The court must declare that the preliminary stage has ended and the re-organization stage has begun, unless the debtor requested the court to start the liquidation procedures. B-The procedures mentioned in chapter 8 of this law shall be applied to the cases in which a pre-made re-organization plan is submitted within 30 days since the date on which the insolvency declaration decision is published. Otherwise, the provisions mentioned in chapter 9 shall be applied to the re-organization process. In case the plan was approved, the preliminary stage ends after the period of filing an appeal against the plan ends or having a court issued upon such an appeal. C-Despite paragraph A of this article, if the report of the insolvency agent suggests that the re- organization is not possible or the operation of the enterprise stopped, the court must issue a decision requiring to start executing the liquidation procedures. That applies unless the debtor filed a written request to the insolvency agent within 10 days since the date on which the latter report was filed on. Such a request must include the debtor's intention to submit a re-organization plan which shall be approved by creditors whose debt value represent $25 \%$ of the whole debt. D-The insolvency agent must submit the request to the court. He must carry out the re- organization procedures when the preliminary sage ends.

Note 17. Article of the Jordanian insolvency law No. 21 of 2018. 
Note 18. Al-Shahawi, Qadri Abed Al-Fatah. The theory of the right to prison someone and the case of civil insolvency. Al-Ma' aref publishing and distribution. Alexandria. $1^{\text {st }}$ edition. 2010. P.121.

Note 19. Al-Sanhuri, Abed Al-Razeq Ahmad. Al-Waseet: Illustration for the civil law. Part 2. The theory of commitment from a general perspective. Second volume. The impact of commitment. Al-Feker Al-Arabi Publishing and distribution house. Cairo.

Note 20. Al-Far, Abed Al-Qader. Provisions regulating commitment: The effects of having rights under the civil law. Al-Thaqafah publishing and distribution Journal. Amman. 2008, $1^{\text {st }}$ edition. P.112.

Note 21. Al-Sanhuri, Al-Waseet: Illustration for the civil law. Part 2, 1575.

Note 22. Al-Dafeery. Insolvency state in the Kuwaiti civil law. Rights Journal. The University of Kuwait. Vol. 35. Issue. 1. 2011. p.149-150.

Note 23. Ammar, Mufti and Al-Sheikh, Bu Samaha. The thematic and procedural aspects of civil insolvency: A comparative study between the Algerian and Egyptian laws. Dafater Journal of Law. Morocco. Issue 2-3, 2017, 112-113.

Note 24. Al-Dafeery. Insolvency state in the Kuwaiti civil law. P.151.

Note 25. Al-Dafeery. Insolvency state in the Kuwaiti civil law. P.151-152.

Note 26. Al-E'kaili, Al-Waseet: Illustration for the commercial law. Part No. 3. P.121.

Note 27. Al-Nemrat, Omar. The legal effects of the bankrupt's transactions in the doubt period according to the Jordanian commerce law: A comparative study with Egyptian commerce law MA thesis. Arab Amman University. 2005, p.26.

Note 28. Al-Dafeery. Insolvency state in the Kuwaiti civil law. P.156.

Note 29. Khalil, The provisions of commercial bankruptcy and civil insolvency, p.61.

Note 30. A judgment issued by the Jordanian court of cassation that holds No. 4152 / 2003 (a five member body). It was issued on 19/5/2004 / The Publication of Justice Centers.

Note 31. Ammar, and Al-Sheikh. The thematic and procedural aspects of civil insolvency, p.115.

Note 32. Al-Dafeery. Insolvency state in the Kuwaiti civil law. P.157.

Note 33. Haitham, Saeed Mohammad. Insolvency and bankruptcy under the legislations of the Republic of Yemen. The Journal of Yemeni Studies. Issue 60-61. 1999. P.162.

Note 34. Ammar, Al-Sheikh. The thematic and procedural aspects of civil insolvency, p.116.

Note 35. Al-Tarawneh, Bassam; and Melhem, Bassam. Illustration for the commercial law: The principles of the commercial law. Al-Maseera publishing and distribution house. Amman. $4^{\text {th }}$ edition. 2017. P.192.

Note 36. A judgment issued by the Jordanian court of cassation that holds No. 3235 / 2014 (a regular body). It was issued on 16/4/2015/ The Publication of Justice Centers.

Note 37. Paragraph a/ article 8 of the Jordanian insolvency law No. 21 of 2018.

Note 38. Paragraph B/ article 8 of the Jordanian insolvency law No. 21 of 2018.

Note 39. Paragraph A/ article 9 of the Jordanian insolvency law No. 21 of 2018.

Note 40. Paragraph B/ article 9 of the Jordanian insolvency law No. 21 of 2018.

Note 41. Article 13 of the Jordanian insolvency law No. 21 of 2018.

Note 42 . Article $191 / 1$ of the Jordanian law of civil proceedings.

Note 43. A judgment issued by the Jordanian court of cassation that holds No. 1236 / 2002 (a five member body). It was issued on 23/5/2002 / The Publication of Justice Centers.

Note 44. A judgment issued by the Jordanian court of cassation that holds No. 3751 / 2011 (a five member body). It was issued on 1/11/2011 / The Publication of Justice Center.

Note 45 . Article 16 of the Jordanian insolvency law No. 21 of 2018.

\section{Copyrights}

Copyright for this article is retained by the author(s), with first publication rights granted to the journal. 
This is an open-access article distributed under the terms and conditions of the Creative Commons Attribution license (http://creativecommons.org/licenses/by/4.0/). 